\title{
Lunar mansions and Timekeeping in Western Islam
}

\author{
Julio Samsó
}

Keywords: Lunar mansions, $m \bar{\imath} q \bar{q}$ t, timekeeping, fajr, folk astronomy, Ibn al-Raqqām, al-Judhāmī, al-Jāzirī.

\begin{abstract}
A working edition of the table of lunar mansions by Ibn al-Raqqām in his Shāmil Zijj, is used as the basis for an analysis of two cases of the use of lunar mansions for the purpose of timekeeping. One of them corresponds to alJudhāmī (an Andalusian author of the end of the $12^{\text {th }} \mathrm{c}$. and beginning of the $13^{\text {th }}$ c.) who uses the mediation of mansions to establish the beginning of dawn and obtains excellent results. The second author is the well-known Moroccan muwaqqit al-Jādirī (1375-c. 1416) whose data on the lunar mansions are also analysed.
\end{abstract}

\section{Lunar mansions in al-Andalus}

Lunar mansions (manzil pl. manāzil) are a set of 28 stars or groups of stars which mark the position of the Moon throughout the lunar sidereal month. The moon stays (yanzil) in each one of them every night of the month and they have, therefore, an obvious application in the construction of calendars. They were used, in Andalusī sources, for magical purposes from the $10^{\text {th }}$ century onwards, as we can see in the Ghäyat al-hakim/Picatrix, ${ }^{1}$ the author

${ }^{1}$ Hellmut Ritter, Pseudo-Mağrițīi, Das Ziel des Weisen. Teubner. Leipzig-Berlin, 1933, pp. 1426. 
of which was probably Abū 1-Qāsim Maslama b. Qāsim al-Qurțubī (d. 353/964), not to be confused with the astronomer and mathematician Maslama b. Ahmad al-Majrịtī (338/950-c.398/1007)2. His contemporary Ibn al-Hâtim had a similar objective in his short work on the making of talismans subject to the influence of the lunar mansions. ${ }^{3}$ This kind of intellectual activity seems to have been undertaken under the caliphate of "Abd al-Raḥmān III al-Nāșir (r. 912-961), a period characterised by a renewal of orthodoxy during which "scientific" astrology almost disappeared or lived a hidden existence. It was probably during this period that the Arabic sources of the Alchandreana collection of Latin texts, compiled in Catalonia towards the end of the $10^{\text {th }} \mathrm{c}$, were written. The Alchandreana often used the lunar mansions for astrological predictions based on very simple methods that had little relation with astronomical techniques. ${ }^{4}$

A different tradition appears in the context of anw $\bar{a}$ ' literature, where the lunar mansions are used for purposes related to timekeeping and other applications of $m \bar{i} q \bar{a} t$ (a specialised kind of astronomy related to the problems posed by Islamic worship). In the first half of the $9^{\text {th }} \mathrm{c}$. the Andalusī polymath 'Abd al-Malik ibn Habīb (d. ca. 238/ 852-53) transmitted a short text on folk astronomy by Malik ibn Anas (d. 179/ 795-96) which has no title in the only extant manuscript, but which is often mentioned as Kitāb fi l-nujūm ${ }^{5}$. In it Ibn Habīb describes the procedure to determine the hour

\footnotetext{
${ }^{2}$ Maribel Fierro, "Bāṭinism in al-Andalus. Maslama b. Qāsim al-Qurțubī (d. 353/964), author of the Rutbat al-Hakim and the Ghāyat al-Hakim (Picatrix)". Studia Islamica 84 (1996), 87112.

${ }^{3}$ D.A. Pingree \& K. Lippincott, "Ibn al-Hātim on the Talismans of the Lunar Mansions", Journal of the Warburg and Courtauld Institutes 50 (1987), 57-81. An edition of the Arabic text, Spanish translation and commentary has been prepared by Marc Oliveras and will be published in al-Qantara.

${ }^{4}$ David Juste, Les Alchandreana primitifs. Etude sur les plus anciens traités astrologiques latins d'origine arabe (Xe siècle). Brill. 2007. On the use of lunar mansions for the prediction of rain, see Charles Burnett, "Lunar Astrology. The Varieties of Texts Using Lunar Mansions with Emphasis on Jafar Indus". Micrologus XII: Il sole e la luna. Firenze, 2004, 43-133 + 7 plates.

${ }^{5}$ Paul Kunitzsch, “Abd al-Malik ibn Habīb's Book on the Stars”. Zeitschrift für Geschichte der Arabisch-Islamischen Wissenschaften 9 (1994), 161-194; 11 (1997), 179-188. Reprint (without the edition of the Arabic text) in M. Fierro and J. Samsó (eds.), The Formation of al-
} 
during the night by observing the lunar mansion that crosses the meridian at a given hour and calculating the number of mansions that have culminated since sunset. As the total number of mansions amounts to 28 , he considers that there are always 14 mansions above the horizon and 14 below it. Therefore, each new mansion that crosses the meridian is assumed to imply that half a seventh of the night has elapsed. The same technique is used, about one century later (ca. 950), by Qāsim ibn Muțarrif al-Qațān in his Kitäb al-hay'a who mentions the use of an instrument (called al-dā'ira, the circle), ${ }^{6}$ also described, towards the end of the $12^{\text {th }}$ c., by Abū 'Alī al-Hasan ibn 'Alī ibn Hasan al-Umawī al-Qurțubī (d. 1205-1206): it consists of a circle divided into 12 hours and a second, movable, circle where the lunar mansions and the zodiacal signs are represented. One places the mansion or the sign of the sun at the end of the semicircle, in the western point of the horizon. The opposite mansion will be the one rising at sunset and it will indicate the hour through its motion across the celestial vault. ${ }^{7}$ Another twelfth-century author who describes a similar method to determine the hour during the night using the lunar mansions is the philologist Ibn Hishām alLakhmī (d. 577/ 1181-82) who wrote a commentary (sharh) on a Qașida fì tarḥil al-nayyirayn, also entitled Qașìda fì l-hay'a, which Ibn Hishām ascribes to the famous scientist Ibn al-Haytham (d. after 432/1040). ${ }^{8}$

The apparent rotation of the lunar mansions is also used by Ibn 'Āșim (d. 403/1013) to determine the moment of the optional night prayer (al-

Andalus. Part 2: Language, Religion, Culture and the Sciences. Ashgate-Variorum. Aldershot, 1998, pp. 277-304.

${ }^{6}$ Josep Casulleras, "The contents of Qāsim ibn Muțarrif al-Qațāan's Kitāb al-hay'a" in M. Fierro and J. Samsó, The Formation of al-Andalus II, 339-358 (see pp. 345-346).

${ }^{7}$ Miquel Forcada, "Mīqāt en los calendarios andalusíes”. Al-Qanțara 11 (1990), 59-69. See also M. Forcada, "El origen del nocturlabio a la luz de fuentes hispánicas y andalusíes". Revista del Instituto Egipcio de Estudios Islámicos en Madrid 27 (1995), 207-219.

${ }^{8}$ I have not been able to find any reference to such a work by Ibn al-Haytham in the lists of his authentic works. See D.A. King, A Survey of the Scientific Manuscripts in the Egyptian National Library. Winona Lake, Indiana, 1986, nos B77 and F10. My friend José Pérez Lázaro sent me, with his usual generosity, his provisional edition of Ibn Hishām's commentary. On this author see J. Pérez Lázaro, Ibn Hišām al-Lajmī, Al-Madjal ilà taqwīm al-lisān wa tà lìm al-bayān (Introducción a la corrección del lenguaje y la enseñanza de la elocuencia. 2 vols. Madrid, 1990. 
tahaijud) and the moment of the last meal before dawn during the month of Ramaḍān $(a l-s a h \bar{u} r)^{9}$. His contemporary, Aḥmad ibn Fāris al-Munajjim (fl. ca. 371/982) is the author of a Mukhtașar min al-anwā' where we find (chapter 15) the dates for each month in which every lunar mansion rises at dawn (fajr), although I am not sure of the precise meaning of the word fajr in this context. ${ }^{10}$ A twelfth-century source, Al-Mu'rib 'an ba'd 'ajā'ib alMaghrib, written by Abū Hāmid al-Gharnāțī (d. 565/ 1169) assumes that as 14 mansions are above the horizon during the night, 12 of them correspond to the period of complete darkness while the rising of the thirteenth mansion coincides with the beginning of dawn. ${ }^{11}$ Finally, in his commentary to the Qașida attributed to Ibn al-Haytham, the aforementioned Ibn Hishām states that, in order to determine the lunar mansion which mediates in the moment of the rising of dawn (fajr), one should count six mansions from the one rising at sunset. ${ }^{12}$

\footnotetext{
${ }^{9}$ Miquel Forcada, Ibn 'Āșim (m. 403/1013). Kitāb al-anwā' wa-l-azmina-al-Qawl fì l-šuhūr(Tratado sobre los anwā' y los tiempos - Capitulo sobre los meses). Barcelona, 1993.
}

${ }^{10}$ Miquel Forcada, "Astrology and Folk Astronomy: the Mukhtașar min al-Anwā' of Ahmad b. Fāris”. Suhayl 1 (2000), 107-205. Chapter 15 appears in pp. 175-191. On this work see also M. Forcada, "A New Andalusian Astronomical Source from the Fourth/ Tenth Century; the Mukhtașar min al-Anwā' of Aḥmad ibn Fāris", in J. Casulleras and J. Samsó (eds.), From Baghdad to Barcelona. Studies in the Islamic Exact Sciences in Honour of Prof. Juan Vernet. Barcelona, 1996. II, pp. 769-780.

${ }^{11}$ Ingrid Bejarano, Abū Hāmid al-Garnāțī (m. 565/1169). Al.Mu'rib 'an ba'ḍ 'aŷà'ib al-Magrib (Elogio de algunas maravillas del Magrib. Madrid, 1991, pp. 134-135 and 65-66 (of the Arabic edition). On this work see also Jean-Charles Ducène, «Le Kitāb Dalā'il al-Qibla d'Ibn al-Qāșș: analyse des trois manuscrits et des emprunts d'Abū Hāmid al-Garnāțī». ZGAIW 14 (2001), 169-187-

${ }^{12}$ David King has reminded me of the existence of a treatise on timekeeping by the lunar mansions authored by a certain Ibn Hārūn al-Șiqillī (MS Dublin CB 4538, copied ca. 1300). The tables in this text, compiled for use in Egypt, "display the configuration of the lunar mansions with respect to the horizon and meridian at each of thirteen times during the night". See D.A. King, In Synchrony with the Heavens. Studies in Astronomical Timekeeping and Instrumentation in Medieval Islamic Civilisation. Vol. I: the Call of the Muezzin. Brill, LeidenBoston, 2004, pp. 512-513. Besides, al-Așbahī (fl. Yemen mid $13^{\text {th }}$ c.) states that 12 mansions rise, every night, before fajr and another 12 set during the same period of time. If both the eastern and the western horizons are cloudy, one can observe the mansion which crosses midheaven. Similar references in the work of his contemporary al-Fārisī who explains a procedure to calculate the hour during the night by observing the mansion which crosses midheaven. See Petra G. Schmidl, Volkstümliche Astronomie im Islamischen Mittelalter. Zur 


\section{Ibn al-Raqqām's table of lunar mansions}

Ibn al-Raqqām is the shuhra of Abū 'Abd Allāh Muhammad b. Ibrāhīm b. 'Alī b. Aḥmad (Muhammad?) b. Yūsuf al-Mursī al-Andalusī al-Tūnisī alAwsī, an astronomer and polymath whose family was probably from Murcia although he lived in Tunis, Bijāya and Granada (after 1273) where he died in $715 / 1315 .^{13}$

He is the author of three zijjes in which he adds three different sets of canons to the unfinished numerical tables of Ibn Isḥāq al-Tūnisī (fl. Tunis and Marrākush ca. 1193-1222). These zijjes were compiled in Tunis or Bijāya between ca. 1280 and 1290 although one of them (al-Zij al-Qawim) was the object of a later adaptation in Granada. The complete titles of the three $z \bar{l} j \mathrm{es}$ are:

- al-Zīj al-Mustawfì li-mā hāza min al-bast wa l-hazz al-awfar wa lqist al-awf $\bar{a}^{I 4}$ (Zijj with which everything acquired through donation and generous fortune in plentiful amount is fully returned). ${ }^{15}$ - al-Zīj al-Shāmil fì tahdhīb al-Kāmil. ${ }^{16}$

Bestimmung der Gebetszeiten und der Qibla bei al-Așbah̄i, Ibn Rah̄ì und al-Fārisī. 2 vols. Brill, Leiden-Boston, 2007, pp. 221-222, 316-322.

${ }^{13}$ See E.S. Kennedy, "The Astronomical Tables of Ibn al-Raqqām a Scientist of Granada". ZGAIW 11 (1997), 35-72. See also J. Samsó, Ibn al-Raqqām, Abu ${ }^{c} A b d$ Allāh. "Biblioteca de al-Andalus. De Ibn al-Labbāna a Ibn al-Ruyūlī". Almería, 2006, pp. 440-444.

${ }^{14}$ This title contains a possible rhyme and this led me to believe that the first word was Mustawfā (rhyme with al-awfāa) which both Díaz-Fajardo and I have used in several publications. George Saliba suggested that Mustawfi was a better option and I follow here his advice.

${ }^{15}$ On this $Z \bar{i} j$ only two studies, on questions of detail, have been published so far: Montse Díaz-Fajardo, "Al-Zîy al-Mustawfà de Ibn al-Raqqām y los apogeos planetarios en la tradición andaluso-magrebí,, Al-Qanțara 26 (2005), 19-30; J. Samsó, "The computation of the degree of mediation of a star or planet in the Andalusian and Maghribī Tradition", in Mathematics Celestial and Terrestrial- Festschrift für Menso Folkerst zum 65. Geburtstag. Acta Historica Leopoldina 54 (2008), 395-404.

${ }^{16}$ A partial edition of the canons and tables in Muhammad 'Abd al-Rahmān, Hisāb ațwāl alkawākib fì l-Zỉj al-Shāmil fì tahdhīb al-Kāmil li-Ibn al-Raqqām. Unpublished Ph.D. dissertation presented at the University of Barcelona in 1996. 
- al-Zïj al-Qawìm fi funūn al-tàdīl wa l-taqwīm.

Both the Mustawfi and the Qawim contain a star table (incomplete in the Mustawfi) which purports to be the result of observations made in Tunis in $680 / 1280-81$. The longitudes are calculated with an increment of $16 ; 46^{\circ}$ on those of the Almagest. After reading a previous draft of this paper, Mercè Comes remarked that the Jāmi' al-mabādi' wa l-ghāàat fì 'ilm al-mīqāt written by Abū 'Alī al-Ḥasan (or Abū l-Hasan 'Alī) al-Marrākushī contains three star tables, two of which are dated in 680/1280-81. These tables contain 246 stars and correspond to: 1) Star longitudes, latitudes and magnitudes for the beginning of the Hijra ${ }^{17}$; 2) Star declinations for year $680 ;{ }^{18} 3$ ) Right ascensions (from the beginning of Capricorn) of the stars for year $680^{19}$. The commentary on the first table (pp. 49 and 60) identifies the beginning of the Hijra with the al-mabda' al-dhätī (beginning of sidereal longitudes) ${ }^{20}$ and, using the trepidation tables of Ibn al-Zarqālluh (whom he calls al-Zarqāl), he gives an example for the computation of the tropical longitude of star Qalb al-Asad ( $\alpha$ Leonis) for year 473/ 1080-81. He states that its longitude was $16 ; 32^{\circ}$ of $\mathrm{Leo}^{21}$ and that this longitude agrees with the observation made by the Toledan astronomer precisely in this year. ${ }^{22}$ In spite

${ }^{17}$ Facsimile edition of the Mabādi' published by Prof. Fuat Sezgin in Frankfurt, 1984, pp. 5059.

${ }^{18}$ Facsimile pp. $80-83$.

${ }^{19}$ Facsimile pp. $130-134$.

${ }^{20}$ On this problem see J. Samsó, “Andalusian astronomy in $14^{\text {th }}$ century Fez, al-Zīj al-Muwāfiq of Ibn 'Azzūz al-Qusanțīn̄’” in Zeitschrift für Geschichte der Arabisch-Islamischen Wissenschaften 11 (1997), 73-110 (cf. especially pp. 107-110). A reprint of this paper in J. Samsó, Astronomy and Astrology in al-Andalus and the Maghrib. Ashgate-Variorum, Aldershot, 2007, no IX.

${ }^{21}$ There is an error of 1' in al-Marrākushī's text in which the longitude is given as $16 ; 33^{\circ}$. My correction is based in the longitude of the star for the beginning of the Hijra $\left(129 ; 7^{\circ}\right)$ to which one should add the calculated iqbāl (precession) which is $7 ; 25^{\circ}$, according to the author, for year 473 .

${ }^{22}$ Actually, according to Ibn al-Zarqālluh's treatise on the motion of the fixed stars (see J.M. Millás Vallicrosa, Estudios sobre Azarquiel, Madrid-Granada, 1943-50, p. 296) the observation was made in 467/1074-75) and the result obtained was between Leo $16 ; 30^{\circ}$ and Leo $16 ; 40^{\circ}$. 
of the coincidence of the dates, al-Marrākushī's star tables do not seem to have anything in common with Ibn al-Raqqām's table. In its most complete version (MS. Rabat Khizāna 'Āmma 260, pp. 100-103) it contains a list of 120 stars, giving, for each one of them, its longitude, latitude, magnitude, mediation, declination, degree of the ecliptic with which it rises and sets, half the day arc and meridian altitude for the latitude of Tunis $\left(36 ; 37^{\circ}\right)$. Only the declination values can be directly compared with those of al-Marrākushī and they are definitely not the same.

As for the Shāmil, extant in a unique MS preserved in Istanbul (Kandilli $249),{ }^{23}$ it was compiled in Bijāya in 679/1279-80, according to the introduction, and it contains a table of the lunar mansions ${ }^{24}$ dated in the MS in 887 (sic, a mistake for $687 / 1288-89$ ?). ${ }^{25}$ The longitudes of the 70 stars mentioned have an increase of $16 ; 50^{\circ}$ on those of the Almagest. ${ }^{26}$ It is possible to imagine that 679 (written in words in the introduction) could also be an error for 689/ 1290.

This is the only table of lunar mansions I am aware of in the Andalusī, or related to Andalusī, tradition. This is why I am editing it here and making a few comparisons with the star tables in the Mustawfi (MS Rabat Khizanna 'Āmma 1461 p. 288) and the Qawim (MS. Rabat Kh. 'Ā. 260 pp. 100-103). I will use it in the rest of the paper, in which I try to analyse methods of timekeeping, based on the lunar mansions, which are more precise than the ones mentioned above, mainly in the anwā' tradition. I have numbered the mansions as well as the 69 stars with coordinates appearing in Ibn alRaqqām's table. Sh and $J$ are shortenings for shimāli (northern, + ) and janūbi (southern, -).

Jadwal li-ma'rifat kawākib al-manāzil al-marșūda li-sanat thamānī mi'a wa $\mathrm{sab}^{\mathrm{a}}$ wa thamānin tabîi iyya (MS Kandilli fols. $85 \mathrm{v}-86 \mathrm{r}$ and v) [Table for

\footnotetext{
${ }^{23}$ I have a copy of this MS thanks to the generosity of Dr. Benno van Dalen.

${ }^{24}$ On this table see Kennedy, "Ibn al-Raqqām” p. 67.

${ }^{25}$ See Mercè Comes, "Some new Maghribī sources dealing with trepidation". Science and Technology in the Islamic World. Turnhout, 2002, pp. 121-141 (especially pp. 130-131).

${ }^{26}$ One star in the mansion of al-Iklïl was not mentioned by Ptolemy and has no coordinates.
} 
the knowledge of the mansions, established through observations made in 887. (The longitudes are) tropical]. (See Table 1)

\section{Al-Judhāmī and his poem on the determination of the beginning of dawn}

My friend Jorge Lirola, editor of the Enciclopedia de al-Andalus, ${ }^{27}$ drew my attention to the figure of Abū Ja'far Ahmad ibn Jumhūr al-Judhāmī (d. Seville 25 Muharram 627/ 14 December 1229) author of a Qașìda fi ma'rifat al-mutawassit min al-manāzil waqt al-fajr, preserved by Ibn 'Abd al-Malik ${ }^{28}$ in which he specifies the lunar mansion crossing midheaven at the moment of the beginning of dawn throughout the solar year in a place with a latitude $37 ; 30^{\circ}$, a value which fits Seville ${ }^{29}$. The beginning of the qașida has a certain interest ${ }^{30}$ and I translate the first fifteen verses here:

I saw many people offering those who were interested some rules, based on the [lunar] mansions, so that they may know [the moment] of dawn (fajr)

They said things which were not true and which gave no profit to those who listened to them ${ }^{31}$

Your eyes will see that things do not agree with what they showed and, so, those having knowledge seem to be ignorant

How often they forced a mansion to rise when it was not rising or to set when it was not setting

And how often the meridian was crossed by a mansion which you could not see mediating, something that was considered as a clear indication of dawn

You have here those [mansions] which crossed the meridian without any need of relying on those traversing the horizon treading on it as a $n \bar{a} z i l^{32}$

\footnotetext{
${ }^{27}$ Three volumes have already appeared in Almería, 2004. 2006 and 2007.

${ }^{28}$ Ibn 'Abd al-Malik al-Marrākushī, al-Dhayl wa'l Takmila li-kitābay al-Mawșūl wa l-Ṣila. Ed. Muḥammad b. Sharīfa vol. I (Beirut, 1971), pp. 209-212 (no 290)

${ }^{29}$ E.S. and M.H. Kennedy, Geographical Coordinates of Localities from Islamic Sources. Frankfurt, 1987, p. 311.

${ }^{30}$ The author states, for example, that he has dealt, elsewhere, with the lunar mansions that rise or set in the moment of the beginning of dawn.

31 Al-sāmiēun in the MS. The editor makes an emendation and reads al-sābiqūn (the predecessors), a correction that does not make much sense.
} 
In agreement with the school of those who make observations and study these problems ('ala madhhab al-arșād wa l-nazarar) and following the opinions of the best scholars

I have followed the brilliant ones (al-nayyirāt) and not taken into consideration a star of reduced light (manqūs) when it is together with a perfect one ( $k \bar{a} m i l)$

I have used the most brilliant [star] of each mansion (dhā l-ishrāq min kull manzil) and omitted a star which is more obscure and has a weak light

When they were equivalent in their light I caught one without allowing it to escape the net of the hunter

With what I have gathered you will obtain the truth adding to it what I said about the rising (tôali $\bar{a} t)$ mansions

And what I also said previously about the setting ones (ghāribāt). This will become obvious for those who make an effort

It is necessary to know the latitude of the city for which the computation has been made, without any deviation

It amounts to thirty degrees plus seven and a half, based on a secure calculation without any uncertainty

I am showing here the truth, as I know it and I pray to the Merciful to preserve me of vain things.

The rest of the poem gives the date in which the lunar mansions cross the meridian.

In order to check the approximate validity of the method, the first problem is to establish which one of the stars of each mansion the author means when he states that this mansion is mediating at the moment of the beginning of dawn in a particular date of the solar year. Al-Judhāmī gives the theoretical solution in the three aforementioned verses when he says:

I have followed the brilliant ones (al-nayyirāt) and not taken into consideration a star of reduced light (manqūss) when it is together with a perfect one ( $k \bar{a} m i l)$

I have used the most brilliant of each mansion (dhä l-ishrāq min kull manzil) and omitted a star which is more obscure and has a weak light

When they were equivalent in their light I caught one without allowing it to escape the net of the hunter

The problem is, however that, out of the 28 lunar mansions, we can use this kind of criterion only in approximately half of them: 7 lunar mansions

\footnotetext{
${ }^{32}$ As we have already seen, the Arabic word for a lunar mansion is manzil, derived from the root NZL which is also the root of the active participle nāzil. The nāzil is obviously the moon which spends each night of the month in a manzil (mansion).
} 
have only one star (Dabarān, Haq'a, Nathra, Șarfa, al-Simāk, al-Qalb and alRishā') while in other 8 (Buțayn, Thurayyā, Han'a, Jabha, Shawla, Balda, $\mathrm{Sa}^{\circ} \mathrm{d} \mathrm{Bula}^{\circ}$ and $\mathrm{Sa}^{\mathrm{e}} \mathrm{d}$ al-Su ūd) there is at least an additional star greater than the relatively faint star which in all strictness marks the beginning of the mansion. This is not the case in the remaining thirteen mansions (Nath, Dhirāe', Țarfa, Zubra, 'Awwā', Ghafr, Zubānā, Iklīl, Na'ā'im, Sa'd alDhābih, Sa'd al-Akhbiya, al-Fargh al-Muqaddam and al-Fargh alMu'akhar).

For that reason I have decided (see Table 2) to calculate the hour of the beginning of dawn (H1), counted from midnight when each star of the 69 mentioned in Ibn al-Raqqām's table of lunar mansions (Table l) crosses midheaven. I have used Ibn al-Raqqām's table as a starting point, even though it is later (probably 687/1288-89) than al-Judhāmī's poem.

In Table 2 we have:

- (1) The date of the solar year given by al-Judhāmī

- (2) The number and name of the lunar mansion

- (3) The identification and magnitude of each of the 69 stars: $n$ indicates a nebula.

- (4) The ecliptic longitude of the star. I have used Ibn alRaqqām's values in Table 1, dated 1288-89. As al-Judhāmī died in 1229 , I have assumed a vaguely approximate date of 12001201. This implies about 87 years before the date of Ibn alRaqqām's table. Using a precession of $1^{\circ}$ per 66 years, the corresponding value will be $1 ; 19^{\circ}$ which I have subtracted from Ibn al-Raqqām's longitudes.

- (5) Med (m) corresponds to the degree of mediation (mediatio coeli, tawassut al-sama $\bar{a}^{\prime}$ ) of each star. It has been calculated using the following expressions:

$$
\begin{aligned}
& \delta=\operatorname{asin}(\sin \beta \cos \varepsilon+\cos \beta \sin \varepsilon \sin \lambda) \\
& \alpha_{0}=\operatorname{acos}(\cos \beta \cos \lambda / \cos \delta) \\
& \mathrm{m}=\operatorname{atan}\left(\tan \alpha_{0} / \cos \varepsilon\right)
\end{aligned}
$$

where

$\delta$ is the star declination

$\beta$ is the star latitude as it appears in Ibn al-Raqqām's table 1

$\varepsilon$ is $23 ; 32,40^{\circ}$, the value used by Ibn al-Raqqām

$\lambda$ is the star longitude in column (4) of Table 2

$\alpha_{0}$ is the right ascension of the star

$m$ is the mediation of the star. 
- (6) The solar longitudes for the corresponding dates of years 1200-1201 have been calculated with a computer program based on the parameters of the Toledan Tables, ${ }^{33}$ which is a $z \bar{l} j$ likely to have been used towards the beginning of the $13^{\text {th }} \mathrm{c}$.

- (7) H1 is the hour (from midnight) at which the corresponding star of columns (3) and (4) is crossing the meridian. One of the alternatives in John North's program HOROSC ${ }^{34}$ has been used for the computation of this hour. The calculation uses the longitude of midheaven (5), the local latitude $\left(37 ; 30^{\circ}\right)$ and the longitude of the Sun (6).

- (8) $\mathrm{H} 2$ is the hour (from midnight) of the beginning of dawn (assuming it corresponds to the hour in which the Sun reaches an altitude of $\left.-18^{\circ}\right)$.

- (9) $\Delta(\mathrm{H} 2)=\mathrm{H} 1-\mathrm{H} 2$

- (10) H3 is the hour (from midnight) of the beginning of dawn (assuming it corresponds to the moment in which the Sun reaches an altitude of $-17^{\circ}$ ).

- $\quad(11) \Delta(\mathrm{H} 3)=\mathrm{H} 1-\mathrm{H} 3$

Med, $\mathrm{H} 2$ and $\mathrm{H} 3$ have been calculated with Benno van Dalen's computer program Table Analysis (specifically with the subprogram Table calculator). For $\mathrm{H} 1$ and $\mathrm{H} 2 \mathrm{I}$ have used the following expressions:

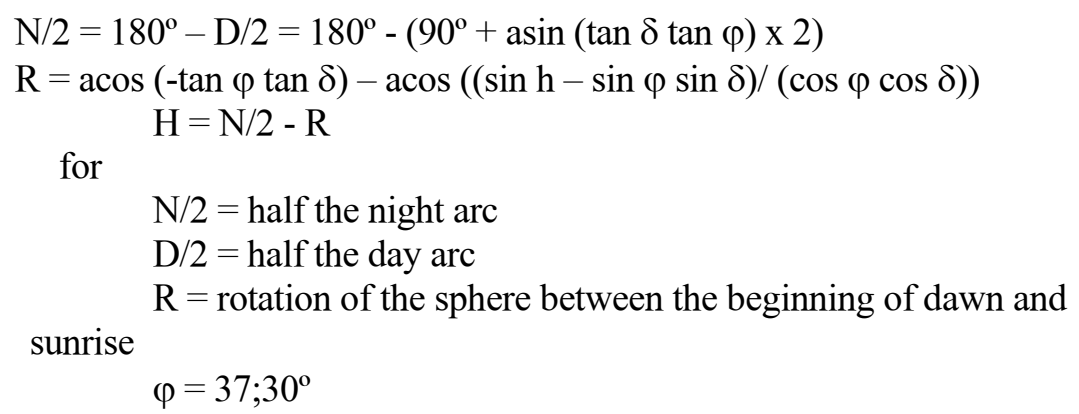

${ }^{33}$ The skeleton of the program was prepared by Prof. E.S. Kennedy during one of his stays in Barcelona. It was afterwards revised by Dr. Honorino Mielgo. My gratitude to both of them.

${ }^{34}$ See John North, Horoscopes and History. The Warburg Institute. London, 1986. 
$\delta=$ declination values corresponding to the solar longitudes calculated with the Toledan Tables.

$\mathrm{h}=-18^{\circ}$ (for $\mathrm{H} 2$ ) or $-17^{\circ}$ (for $\mathrm{H} 3$ )

An analysis of the results obtained with Table 3 leads me to the following conclusions:

Al-Judhāmī seems to be using a negative altitude of the Sun of $-17^{\circ}$. The results obtained are much better than when we use $-18^{\circ}$. The parameter $-17^{\circ}$ was also used to calculate the data related to the length of dawn in the Calendar of Cordova ${ }^{35}$, although the standard value in al-Andalus was $-18^{\circ}$ and Ibn Mu'ādh al-Jayyānī (b. 989) used $-19^{\circ 36}$. The results obtained are surprisingly good in a source which corresponds to the tradition of folk astronomy and for which we know neither the precise date nor the astronomical tables used. I have marked with an asterisk the star giving the best results and it is easy to see that, in most cases, this star is the one with greater magnitude. There are three exceptions, however, which correspond to mansions 20 (al-Na'a 'im), 21 (al-Balda) and 24 (Sa'd al-Su'īd). A statistic based on column (11) shows the following list of errors in which only the stars marked with an asterisk have been considered:

0 minutes in 3 cases

\pm 1 min. in 3 cases

$\pm 2 \mathrm{~min}$. in 3 cases

\pm 3 min. in 6 cases

\pm 4 min. in 2 cases

\pm 5 min. in 1 case

\footnotetext{
${ }^{35}$ See J. Samsó, "Sobre los materiales astronómicos en el "Calendario de Córdoba" y en su versión latina del siglo XIII", in J. Vernet (ed.), Nuevos Estudios sobre Astronomía Española en el Siglo de Alfonso X. Barcelona, 1983, pp. 125-138 (especially pp. 131-135). Reprint in Samsó, Islamic Astronomy and Medieval Spain. Variorum. Aldershot, 1994, no. V.

${ }^{36}$ See B.R. Goldstein, "Ibn Mu'ādh's Treatise on Twilight and the Height of the Atmosphere", Archive for the History of the Exact Sciences 17 (1977), 97-118. For other values in the Maghribī astronomical tradition see J. Samsó, "Astronomical observations in the Maghrib in the fourteenth and fifteenth centuries". Science in Context 14 (2001), 165-178 (esp. pp. 174175). This paper has been reprinted in Samsó, Astronomy and Astrology in al-Andalus and the Maghrib. Ashgate-Variorum. Aldershot, 2007, no XII.
} 
\pm 6 min. in 3 cases

which implies that in 21 cases out of 28 the error can be considered acceptable. Greater errors will be found in

Mansion 12: $-23 \mathrm{~min}$.

Mansion 14: -19 min.

Mansion 16: +13 min.

Mansion 17: -39 min.

Mansion 18: -15 min.

Mansion 19: -39 min.

Mansion 22: -36 min.

Interestingly, mansions $12-18$ cross the meridian during the winter. (See Table 2)

\section{Lunar mansions in al-Jādirī}

Abū Zayd 'Abd al-Raḥmān b. Abī Ghālib Muḥammad, known as al-Jādirī was born in Meknes in 777/1375 and died in Fez probably in 818/1416. He was muwaqqit of the Qarawiyyīn mosque in Fez and wrote one of the most popular Maghribī treatises on timekeeping: the urjūza entitled Rawdat alazhār fi 'ilm waqt al-layl wa l-nahār, compiled in Fez in 794/1391-92. ${ }^{37}$ This urjüza was the object of several commentaries, among which I am using here the anonymous Natā'ij al-afkār fì sharh Rawdat al-azhār, written in Tilimsān/ Tlemcen ca. 920/ 1514-15, preserved in MSS London British Library Or. 411 and Cairo Dār al-Kutub K4311 ${ }^{38}$ Al-Jādirī is also the author of a summary of the Rawdat al-azhār entitled Iqtitāf al-anwār min Rawdat al-azhār edited by Muhammad al-Khatțābî ${ }^{-39}$ and studied by Emilia Calvo ${ }^{40}$.

37 D.A. King, Survey p. 139, no. F26; Driss Lamrabet, Introduction à l'histoire des mathématiques maghrebines. Rabat, 1994, p. 114.

${ }^{38}$ J. Samsó, "An Outline of the History of Maghribī Zijes from the end of the thirteenth century". Journal for the History of Astronomy 29 (1998), 93-102; J. Samsó, “Astronomical Observations...". Both papers have been reprinted in Samsó, Astronomy and Astrology nos. XI-XII. Mercè Comes, "Some new Maghribī sources" pp. 123-124. I am using here a provisional edition of the Natâ 'ij prepared by my postgraduate student Rachid Saidi.

${ }^{39}$ M. al-Khaț̣ābī, 'Tlm al-mawāqūt. Muhammadiyya, 1986. 
Finally, he also wrote a calendar with the title Tanbìh al-anām 'ala $m \bar{a}$ yah̆duthu fì ayyām al- $\bar{a} \bar{a}$, finished on $15^{\text {th }}$ Jumādā II $801\left(21^{\text {st }}\right.$ February 1399), which seems to be an adaptation to the latitude of Fez of a Taqyid written by Ibn al-Bannāa, ${ }^{41}$ An incomplete copy of this calendar (March, April, May and the beginning of June are missing) is preserved in MS 80 of the Zāwiya Hamzawiyya pp. 174-184. ${ }^{42}$ A working edition of this calendar was prepared by Amal Boujenna for her D.E.A. ("Diploma of Advanced Study") in 2005 and I use the information in her work. In the two works of al-Jādirī (Rawḍ and Tanbīh) I find the following data which have a certain interest for the purposes of this paper:

- Rawda: it contains a complete list of the mediations (tawassut) of the 28 lunar mansions as well as the declinations of eight of them.

- Tanbih: it gives the position of the Sun in the 28 lunar mansions through the solar year although, as I have already said, the months of March, April, May and the beginning of June are missing in the Hamzawiyya MS.

As in the other parts of this paper, my starting point will be Ibn alRaqqām's table of lunar mansions in his Shāmil Zỉj. Apart from other reasons, al-Jādirī quotes only the observations of two authorities at the beginning of the verses of the Rawda on the mediations of the lunar mansions: a certain al-Sabtī and Raqqām [sic] al-Awsī. The former might be the author of some tables which appear in the Hyderabad recension of the $z \bar{j} j$ of Ibn Ishāāq. ${ }^{43}$ As for [Ibn] al-Raqqām, al-Jādirī does not identify which of his $z \bar{l} j$ es he is using, although his anonymous commentator does mention the

${ }^{40}$ E. Calvo, "Two Treatises on Mīqāt from the Maghrib (14 $4^{\text {th }}$ and $15^{\text {th }}$ Centuries A.D.)", Suhayl 4 (2004), 159-206.

${ }^{41}$ M. Forcada, "Les sources andalouses du calendrier d'Ibn al-Bannā' de Marrakech“. Actas del II Congreso Hispano-Marroquí de Ciencias Históricas. Historia, Ciencia y Sociedad. Madrid, 1992, pp. 183-196.

${ }^{42}$ Ahmad Alkuwayfi and Mònica Rius, "Descripción del manuscrito 80 de al-Zāwiya alHamzawìya”. Al-Qanțara 19 (1998), 445-463 (see especially pp. 454-455).

\footnotetext{
${ }^{43}$ See Angel Mestres, "Maghribī Astronomy in the $13^{\text {th }}$ Century: a Description of Manuscript Hyderabad Andra Pradesh State Library 298". J. Casulleras and J. Samsó (eds.), From Baghdad to Barcelona (Barcelona, 1996) I, 383-443 (see p. 383 fn. 3).
} 
Mustawfi $Z \bar{i} j$. In any case, it seems clear that al-Jādirī bases his computations on a $z \bar{l} j$ which, like the three $z \bar{i} j$ es of Ibn al-Raqqām, uses the parameters of Ibn Ishāa. We can check this by comparing the solar longitudes for the beginning of each solar month mentioned by al-Jādirī in the Tanbīh with the recomputations made with a computer program based on the parameters of Ibn Ishāa ${ }^{44}$ The year used is 1393 and, as the program gives sidereal longitudes, I have increased them by $11 ; 1^{\circ}$, due to the fact that Ibn alRaqqām uses a constant of precession of $9 ; 26^{\circ 45}$, to which I have added $1 ; 35^{\circ}$ which corresponds, approximately, to the increase in precession of $1 \% 66$ years, the constant used by al-Jāzirī. In table 3 we can see the results which reach a maximum error of $1^{\circ}$, which is acceptable given the kind of source involved (see Table 3).

A second check can be made with the values of the declinations of eight lunar mansions given by al-Jādirī himself in the Rawda. These values have been recomputed with the same expression used above in 3:

$$
\delta=\operatorname{asin}(\sin \beta \cos \varepsilon+\cos \beta \sin \varepsilon \sin \lambda)
$$

My starting point has been Ibn al-Raqqām's table of lunar mansions with the star longitudes increased by $1 ; 35^{\circ}$ and the same stellar latitudes. The results can be seen in Table 4 in which we have 1) the number and name of the lunar mansion, 2) the value of the declination given by al-Jâzirī, 3) the identification of the star with the number given for each one of them in Table 1 , and 4) the recomputed value of the declination for each star. The stars which give reasonable results are marked with an asterisk. These are generally fairly good with the only exception of mansion 4 (al-Dabarān) in which the $15 ; 30^{\circ}$ given by al-Jāzirī in abjad notation ( $y h . l$ ) is probably an error for $25 ; 30^{\circ}(k h . l)$. (See Table 4 )

Finally, Table 5 is an attempt to check al-Jādirī's values for the entrance of the Sun in the lunar mansions, as quoted in the Tanbïh, as well as his values for the mediation of each lunar mansion in the Rawda. Column (1) gives the corresponding date of the solar year in the Tanbih; (2) the number

${ }^{44}$ Again, the skeleton of the program was designed by Prof. E.S. Kennedy and, later, revised by Drs Honorino Mielgo and Josep Casulleras. My gratitude to all of them.

${ }^{45}$ Montse Díaz Fajardo, La teoría de la trepidación en un astrónomo marroquí del siglo XV. Estudio y edición crítica del Kitāb al-adwār fī tasyīr al anwār (parte primera) de $A b \bar{u}{ }^{\circ} A b d$ Allāh al-Baqqār. Barcelona, 2001, pp. 55-57. 
and name of the lunar mansion in which the Sun enters in the aforementioned date; (3) identifies the stars in each mansion and uses, once more, the corresponding number in Ibn al-Raqqām's table of mansions; (4) gives the longitude of each star using Ibn al-Raqqām's longitudes increased in $1 ; 35^{\circ} ;(5)$ is the solar longitude for the dates of column (1) of year 1393; (6) contains the values for the mediation of each mansion given by al-Jādirī in the Rawda; (7) gives the recomputed values of the mediation of each star in (3) calculated using the same expressions as in 3:

$$
\begin{aligned}
& \delta=\operatorname{asin}(\sin \beta \cos \varepsilon+\cos \beta \sin \varepsilon \sin \lambda) \\
& \alpha_{0}=\operatorname{acos}(\cos \beta \cos \lambda / \cos \delta) \\
& \mathrm{m}=\operatorname{atan}\left(\tan \alpha_{0} / \cos \varepsilon\right)
\end{aligned}
$$

These values have, again, been calculated using Benno van Dalen's program Table Analysis. I have also added, in columns (6) and (7) those mansions $(27-28,1-5)$ for which I have no information about the entrance of the Sun, due to the incompleteness of the Hamzawiyya MS, but whose mediation is given in the Rawda.

The best results in each case (coincidence of the solar longitude with the longitude of the star and agreement between the values of the mediation given by al-Jādirī with the recomputed ones) are marked with an asterisk. This gives us a clue for determining the actual stars used by al-Jādirī to identify the lunar mansions, although in one case (mansion 25) the best result in column (4) does not agree with column (7). In other cases (see mansions $26,11,12,16)$ the star longitude does not coincide with the longitude of the Sun while we do find a star with a mediation agreeing with the one in al-Jādirī. Total disagreement in both columns is found in mansions 9, 15, 17 and 21. (See Table 5)

\section{Conclusions}

In these pages I have tried to study two cases of the use of the lunar mansions for the purpose of timekeeping: one of them corresponds to an otherwise unknown Andalusi author of the end of the $12^{\text {th }}$ and beginning of the $13^{\text {th }} \mathrm{c}$. who uses the mediation of the mansions to establish the beginning of dawn and obtains results which are surprisingly good. He seems also to have studied the mansions rising or setting at this moment, although his work on the topic does not seem to be extant. The case is highly uncommon in an Andalusī context in which our knowledge of $m \bar{\imath} q \bar{a} t$ is usually restricted to the information we can gather from the anw $\bar{a}$ ' literature based on accurate astronomical sources (the case of the Calendar of Cordova, for example) or 
on a tradition of folk astronomy (Ibn Habīb). This is why al-Judhāmî’s verses acquire a certain interest for the development of Andalusī astronomy.

The second instance is far more common. We know of the existence of an important $m \bar{l} q \bar{a} t$ tradition in the medieval Maghrib and one of the most important authors is precisely al-Jādirī, whose study has only begun with the aforementioned paper by Emilia Calvo on the Iqtităf al-anwär. The remaining sources are practically unexplored and we have only an important study by Mònica Rius on the problem of the qibla in which she underlines the quantity of Maghribi sources in comparison to the scarcity of the Andalusī ones. ${ }^{46}$ All this in spite of the fact that the figure of the Andalusi professional muwaqqit appeared in Granada in the $14^{\text {th }} \mathrm{c}$.

To the two aforementioned topics I have added a working edition of Ibn al-Raqqām's table of lunar mansions preserved in the Shāmil Zij. This gave me a starting point in an attempt to establish which stars, in each lunar mansion, were used by both al-Judhāmī and al-Jādirī for their computations of the star mediating at the beginning of dawn or occupied by the Sun at a given date in the solar year. Such a use could probably be considered abusive in the case of al-Judhāmī (although I have tried to correct the stellar longitudes to adapt them to the beginning of the $13^{\text {th }} \mathrm{c}$.) but I believe that it is correct for al-Jādirī who, no doubt, uses one of Ibn al-Raqqām's zijjes (or another one belonging to the tradition of Ibn Ishạq) to calculate the position of the Sun as well as of the other celestial bodies.

\section{Acknowledgements}

Jorge Lirola attracted my attention to al-Judhāmī’s poem. José Pérez Lázaro sent me a photocopy of his edition of Ibn Hishām's commentary on the urjüza attributed to Ibn al-Haytham. Benno van Dalen gave me a CDRom which contained photographs of the Kandilli MS of the Shamil Zijj, which was later printed for me by Carlos Dorce. Photographs of the Rabat MS of the Mustawfi Zij were kindly offered to me, some eleven years ago, by Prof. Fuat Sezgin. I have used unpublished materials prepared by Amal Boujenna and Rachid Saidi. John North, Mercè Comes, David King and Miquel Forcada have read a draft of this paper and made useful suggestions. John North's comments were his last service to me after a period of many years in which he was one of my best friends and masters. Finally I have made

\footnotetext{
${ }^{46}$ M. Rius, La alquibla en al-Andalus y al-Magrib al-Aqșà. Barcelona, 2000.
} 
extensive use of computer programs prepared by John North (HOROSC), Benno van Dalen (Table Analysis, Calh), E.S. Kennedy, Honorino Mielgo and Josep Casulleras (Toledan Tables, Ibn Isḥāq's Zīj). My gratitude to all of them. 
Table 1 
Table 2 
Table 3

\begin{tabular}{|c|c|c|c|}
\hline 1) Mansion & 2) Jäzirì's $\delta$ & 3) Star & 4) Recomp. $\delta$ \\
\hline 4. al-Dabarān & $15 ; 30^{\circ}$ & {$[10] \propto T a u$} & $25 ; 31^{\circ}$ \\
\hline \multirow[t]{2}{*}{ 7. al-Dhirāe } & $29^{\circ}$ & {$[14] \alpha$ Gem } & $32 ; 39^{\circ}$ \\
\hline & & $*[15] \beta$ Gem & $28 ; 54^{\circ}$ \\
\hline \multirow[t]{2}{*}{ 11. al-Zubra } & $23^{\circ}$ & $*[23] \delta \mathrm{Leo}$ & $23 ; 17^{\circ}$ \\
\hline & & [24] $\theta$ Leo & $18 ; 47^{\circ}$ \\
\hline 12. al-Șarfa & $18^{\circ}$ & $*[25] \beta$ Leo & $17 ; 38^{\circ}$ \\
\hline 14. al-Simāk & $-8^{\circ}$ & $*[31] \alpha \operatorname{Vrg}$ & $-7 ; 49^{\circ}$ \\
\hline 18. al-Qalb & $-24^{\circ}$ & $*[39] \propto S c o$ & $-24 ; 52^{\circ}$ \\
\hline \multirow[t]{2}{*}{ 26. al-Muqaddam } & $24 ; 30^{\circ}$ & $*[65] \beta P e g$ & $24 ; 35^{\circ}$ \\
\hline & & {$[66] \alpha P e g$} & $12 ; 13^{\circ}$ \\
\hline 28. al-Rishā' & $33^{\circ}$ & $*[69] \beta$ And & $32 ; 50^{\circ}$ \\
\hline
\end{tabular}


Table 4

\begin{tabular}{|c|c|c|}
\hline 1 Jan & $288^{\circ}$ & $289 ; 2^{\circ}$ \\
\hline 1 Febr. & $319^{\circ}$ & $320 ; 24^{\mathrm{o}}$ \\
\hline ......... & ......... & .......... \\
\hline 1 Jul. & $106^{\circ}$ & $106 ; 21^{\circ}$ \\
\hline 1 Aug. & $136^{\circ}$ & $136 ; 6^{\circ}$ \\
\hline 1 Sept. & $166^{\circ}$ & $166 ; 11^{\circ}$ \\
\hline 1 Oct. & $195^{\circ}$ & $195 ; 46^{\circ}$ \\
\hline 1 Nov. & $226^{\circ}$ & $226 ; 49^{\circ}$ \\
\hline 1 Dec. & $257^{\circ}$ & $257 ; 14^{\mathrm{o}}$ \\
\hline
\end{tabular}


Table 5 
